\title{
Seroepidemiology of leptospirosis in pet dogs in the urban area of the municipality of Jataizinho, Paraná
}

\section{Soroepidemiologia da leptospirose em cães domiciliados na área urbana do município de Jataizinho, Paraná}

\author{
Aline do Nascimento Benitez ${ }^{*}$; Daniela Dib Gonçalves ${ }^{2}$; Roberta Lemos Freire ${ }^{3}$; \\ Wagner Borges Rodrigues ${ }^{1}$; Vilma Rodrigues Almeida de Souza ${ }^{1}$; \\ Jean Carlos Alves Barbara ${ }^{1}$; Julio Cesar de Freitas ${ }^{3}$
}

\begin{abstract}
The study of the prevalence of anti-leptospiral antibodies in pet dogs in urban areas and the variables associated with the risk of infection can aid in the identification of the serovars present in the region and indicated the reservoirs involved in this important zoonosis. The aim of the present study was to determine the prevalence of anti-leptospiral antibodies in 653 dogs from 369 households distributed throughout the urban area of the municipality of Jataizinho, Paraná (PR), and to investigate the variables associated with the risk of leptospiral infection in these animals. Serum samples were subjected to microscopic agglutination test (MAT) against 23 serovars of pathogenic leptospires. Among the 132 (20.21\%) reactive samples, $15(11.36 \%)$ were reactive for more than one serovar, and the most likely serovar could not be determined. Among the $117(88.73 \%)$ samples that reacted to a single serovar, the serovar Canicola was considered to be the most likely in 89 cases $(76.07 \%)$. Variables associated with the risk of disease were investigated using an epidemiological questionnaire administered to each owner, and the data obtained were analyzed using the statistical software EpiInfo. The significant variables $(\mathrm{p} \leq$ 0.05 ) associated with seropositivity for leptospirosis in pet dogs in the urban area of the municipality of Jataizinho, PR, were the presence of rats in the household, adult or elderly dogs, free access of the dog to the street and contact with stray dogs. The results indicate a high prevalence of pet dogs in the urban area of Jataizinho, PR, with anti-leptospiral antibodies and suggest the need to educate the population of the municipality about the vaccination of dogs, as well as, the epidemiological role of the dog in urban leptospirosis.
\end{abstract}

Key words: Epidemiology, microscopic agglutination, test, Leptospira spp., serovar Canicola, diagnosis, risk variables

\section{Resumo}

O estudo da prevalência de cães domiciliados em áreas urbanas com anticorpos antileptospiras e de variáveis associadas ao risco de infecção, pode auxiliar na identificação dos sorovares presentes na região e sugerir os reservatórios envolvidos nesta importante zoonose. O objetivo deste trabalho foi determinar a prevalência de anticorpos antileptospiras em 653 cães de 369 domicílios distribuídos na área urbana do município de Jataizinho, PR, e estudar variáveis associadas ao risco de infecção por leptospiras nesses animais. As amostras de soro foram submetidas a prova de soroaglutinação microscópica (SAM)

1 Discente(s), Universidade Estadual de Londrina, UEL, Londrina, PR. E-mail: aline_vetuel@hotmail.com; wagnermedvet@ hotmail.com; wrvninha@hotmail.com; alves2005@yahoo.com.br

2 Prof ${ }^{a}$. Universidade Paranaense, Umuarama, PR. E-mail: danieladibg@hotmail.com

3 Profs. Drs. da UEL, Londrina, PR. E-mail: rlfreire@uel.br; freitasj@uel.br

Author for correspondence 
frente a 23 sorovares de leptospiras patogênicas. Das 132 (20,21\%) amostras de cães reagentes, 15 $(11,36 \%)$ reagiram para mais de um sorovar, não sendo possível determinar o sorovar mais provável, e das 117 (88,73\%) que reagiram para um sorovar somente, o sorovar Canicola foi considerado o mais provável em 89 (76,07\%). Variáveis associadas ao risco da doença foram investigadas através de um questionário epidemiológico aplicado a cada proprietário e os dados obtidos foram analisados pelo programa estatístico EpiInfo. As variáveis significativas $(\mathrm{p} \leq 0,05)$ associadas à soropositividade para leptospirose nos cães domiciliados em área urbana do município de Jataizinho, PR, foram: visualizar ratos no ambiente familiar, animal adulto ou idoso, livre acesso do cão à rua e contato com cães errantes. Os resultados indicam uma alta prevalência de cães domiciliados em área urbana de Jataizinho, PR, com anticorpos antileptospiras e sugerem a necessidade de conscientizar a população do município sobre a vacinação dos cães, assim como, o papel epidemiológico do cão na leptospirose urbana.

Palavras-chave: Epidemiologia, soroaglutinação microscópica, Leptospira spp, sorovar Canicola, diagnóstico, variáveis de risco

\section{Introduction}

Leptospirosis is an important zoonosis caused by the spirochete Leptospira interrogans that affects all mammalian species. The disease has a worldwide distribution and can cause systemic infection with different clinical presentations, according the animal specie and the infecting serovar involved (FAINE et al., 1999).

Dogs are susceptible to all leptospiral serovars; however, when infected by serovar Canicola, they can act as asymptomatic carriers, eliminating the bacteria in the urine without any clinical presentation suggestive of leptospirosis (PRESCOTT, 2008).

In urban environments, dogs are the main reservoirs involved in the transmission of leptospirosis to humans and other dogs (BROD et al., 2005). Jansen et al. (2005) and Fraga (2008) associated the risk of human infection with the presence of dogs infected by leptospires inside the household or near it.

Several studies on pet and stray dogs have identified different variables associated with the risk of infection by leptospires, such as gender, age, presence of flooded areas near the household, contact with rodents, hunting habits and type of access to the street (RUBEL et al., 1997; MASCOLLI et al., 2002; QUERINO et al., 2003; LOPES et al., 2005; MAGALHÃES et al., 2007).
Rubel et al. (1997) consider that the transmission of leptospirosis in stray dogs can occur through direct contact with asymptomatic carriers or indirectly through contact with an environment contaminated by leptospires. Humid soils and stagnant water are important routes of infection for dogs that urinate, drink and walk over these microenvironments that favor the survival of leptospires for months (TRUEBA et al., 2004).

The immunization of dogs can prevent canine leptospirosis. Non-vaccinated populations can reach an incidence of disease of $75 \%$ of dogs (WARD, 2002).

Vaccines against leptospirosis are bacterins and produce a serovar-specific response, with no crossprotection between serotypes. Nonspecific vaccine titers can be detected by a microscopic agglutination test (MAT) up to three months after immunization (MILLER et al., 2011). Harkin et al. (2003) and Minke et al. (2009) showed that the vaccines prevent renal colonization, leptospiruria over long periods and death after extreme challenges in experimental infections.

The aim of the present study was to determine the prevalence and identify the risk variables associated with leptospirosis in pet dogs in the urban area of the municipality of Jataizinho, Paraná (PR). 


\section{Materials and Methods}

\section{Information on the city of Jataizinho, $P R$}

The municipality of Jataizinho, PR, is located 79 $\mathrm{km}$ from Londrina, PR, with an area of $159.18 \mathrm{Km}^{2}$ and 11,875 inhabitants. According to the Brazilian Institute of Geography and Statistics (INSTITUTO BRASILEIRO DE GEOGRAFIA E ESTATÍSTICA - IBGE, 2010), $12.8 \%$ of permanent private households in the urban area have inadequate sanitation, and the monthly household income per capita in this area is $\mathrm{R} \$ 478.00$.

The urban geographical area of the municipality was divided by the Epidemiological Surveillance, together with the Municipal Health Department, into five independent districts that correspond to the coverage area of the Basic Health Units (BHUs) in the municipality as a strategy for the implementation of health programs.

\section{Households}

In 2009, the urban area of Jataizinho-PR had 4,692 properties, of which $80 \%(3,754)$ were family households registered in the Family Health Program of the BHU, with 13,286 registered individuals and an average of 3.54 individuals per household.

\section{Sample size}

In urban areas, the human: $\operatorname{dog}$ ratio is $4: 1$, and $92.70 \%$ of these dogs are domicilieted (ALVES et al., 2005). Therefore, the initial population of pet dogs in Jataizinho, PR, was estimated at 3,079 animals.

The calculation of the sample size was performed using the software Epi 6.0 (DEAN et al., 1994), with an expected prevalence of $50 \%$, accuracy of $5 \%$ and level of confidence of $95 \%$. The size of the sample obtained was multiplied by 1.5 (design effect Deff) as a way of correcting for cluster sampling, totalizing 513 dogs.

\section{Sampling}

A $20 \%$ loss in visitation was estimated considering dogs younger than six months, dogs with aggressive behavior, refusal of the owner to participate in the study and closed houses. Six hundred and twenty households were visited, which were distributed into 42 randomly selected blocks, proportional to the number of households in each region and based on 15 households per block.

\section{Sample collection}

Sample collection was performed between July and November 2010, and an informed consent form was signed by the animal's owner before each collection.

A household epidemiological questionnaire was administered to the owners that contained the following variables: accumulation of rainwater near or in the yard; sewage and garbage disposal; vacant land; flooded areas; presence of rivers, lakes or forests near the household; observation of rats in the household; and presence of a toilet and debris outside the house. The following variables were investigated for each dog: gender; age; breed; vaccination history; contact with other dogs in the household or stray dogs, rodents, cattle or possums; access to the street; type of access, alone or accompanied by the owner; and hunting habits. A blood sample was collected from each dog to obtain serum samples, which were placed in sterile flasks, labeled and stored at $-20^{\circ} \mathrm{C}$ until processing.

\section{Microscopic agglutination test (MAT)}

All of the serum samples were tested for antiLeptospira spp. antibodies against 23 reference serovars: Australis, Bratislava, Autumnalis, Butembo, Castellonis, Bataviae, Canicola, Fortbragg, Whitcombi, Cynopteri, Grippotyphosa, Hebdomadis, Copenhageni, Icterohaemorrhagiae, Panama, Pomona, Pyrogenes, Hardjo, Wolffi, Shermani, Tarassovi, Sentot and Ballum. 
The cultures used as antigens were kept at $28^{\circ} \mathrm{C}$ for 5 to 10 days in Ellinghausen-McCulloughJohnson-Harris (EMJH) medium (DIFCO ${ }^{\circledR}$ - USA) modified by the addition of rabbit serum (FAINE, 1982). The sera were considered to be reactive when at least $50 \%$ of leptospires were agglutinated, starting at a titer of 100 and geometrically diluting by two for the determination of the maximum positive dilution (FAINE et al., 1999). The serovar presenting the highest agglutinating titer was considered to be the most likely serovar (VASCONCELLOS et al., 1997). Only the sera presenting coagglutination in the highest dilution were considered to be reactive to Leptospira interrogans (ALMEIDA et al., 1994).

\section{Statistical analysis}

The data obtained from the epidemiological questionnaire and the results of serodiagnosis were analyzed with the software EpiInfo (DEAN et al., 1994). The Chi-squared test or Fisher's Exact Test were used to determine the statistical significance of the data. The strength of the association was determined by calculating the odds ratio $(95 \%$ confidence interval). A 5\% level of significance was adopted.

\section{Results}

Blood samples were collected from 653 dogs in 369 households distributed into five regions of the urban area of the municipality of Jataizinho, PR.

Among the 132/653 (20.21\%) reactive samples, $15 / 132(11.36 \%)$ were reactive for more than one serotype, and the most likely serovar could not be determined; whereas of the 117/132 (88.73\%) samples that reacted to a single serovar, Canicola was the most likely serovar in 89 (76.07\%) samples.

The most likely serovars detected were Canicola, Butembo, Pyrogenes, Grippotyphosa, Ballum, Bratislava, Copenhageni, Pomona and Tarassovi, with titers varying between 100 and 12.800 (Table 1).

The significant variables $(\mathrm{p} \leq 0.05)$ associated with seropositivity for leptospirosis in dogs were the presence of rats in the household, adult or elderly dogs, free access to the street and contact with stray dogs (Table 2).

Table 1. The most likely serovars of Leptospira interrogans and the titers detected in the microscopic agglutination test (MAT) in 117 pet dogs in the urban area of Jataizinho, PR, between July and November 2010.

\begin{tabular}{cccccccccc}
\hline Titers & $\mathbf{1 0 0}$ & $\mathbf{2 0 0}$ & $\mathbf{4 0 0}$ & $\mathbf{8 0 0}$ & $\mathbf{1 6 0 0}$ & $\mathbf{3 2 0 0}$ & $\mathbf{6 4 0 0}$ & $\mathbf{1 2 8 0 0}$ & Total (\%) \\
\hline Canicola & 30 & 28 & 14 & 09 & 03 & 03 & 01 & 01 & $89(76.07)$ \\
Butembo & 02 & 02 & 01 & 02 & & & & & $07(5.99)$ \\
Pyrogenes & 05 & & & & & & & & $05(4.27)$ \\
Grippotyphosa & 03 & 02 & & & & & & & $05(4.27)$ \\
Ballum & 03 & & 01 & & & & & & $04(3.42)$ \\
Bratislava & 03 & & & & & & & & $03(2.57)$ \\
Copenhageni & 01 & & & 01 & & & & & $02(1.69)$ \\
Pomona & 01 & & & & & & & & $01(0.85)$ \\
Tarassovi & 01 & & & & & & & & $01(0.85)$ \\
\hline Total & 49 & 32 & 16 & 12 & 03 & 03 & 01 & 01 & 117 \\
$(\%)$ & $(41.89)$ & $(27.35)$ & $(13.67)$ & $(10.26)$ & $(2.57)$ & $(2.57)$ & $(0.85)$ & $(0.85)$ & $(100.00)$ \\
\hline
\end{tabular}

Source: Elaboration of the authors. 
Table 2. Analysis of the variables associated with the risk of infection by Leptospira spp. evaluated in 653 pet dogs in the urban area of the municipality of Jataizinho, PR, between July and November 2010.

\begin{tabular}{|c|c|c|c|}
\hline & Reactive/Total (\%) & $\begin{array}{c}\text { OR } \\
(95 \% \mathrm{CI})\end{array}$ & $\mathbf{p}$ \\
\hline \multicolumn{4}{|c|}{ Observation of rats in the household } \\
\hline Yes & $107 / 482(22.2)$ & 1.65 & \\
\hline No & $25 / 170(14.7)$ & $(1.02-2.66)$ & 0.047 \\
\hline \multicolumn{4}{|l|}{ Contact with stray dogs } \\
\hline Yes & $81 / 338(24.0)$ & 1.63 & \\
\hline No & $51 / 315(16.2)$ & $(1.10-2.41)$ & 0.017 \\
\hline \multicolumn{4}{|l|}{ Age } \\
\hline Puppy (a) & $9 / 80(10.0)$ & & \\
\hline Adult (b) & $96 / 4371(20.6)$ & $\begin{array}{c}2.3 \\
(1.11-4.74)\end{array}$ & 0.0308 \\
\hline Elderly (b) & $27 / 70(27.8)$ & $\begin{array}{c}3.42 \\
(1.51-7.78)\end{array}$ & 0.0041 \\
\hline \multicolumn{4}{|l|}{ Type of access } \\
\hline Restrict (c) & $8 / 61(13.1)$ & & \\
\hline Partial (c) & 28/149 (18.8) & $\begin{array}{c}1.53 \\
(0.65-3.58)\end{array}$ & 0.0429 \\
\hline Free $(\mathrm{d})$ & 43/137 (31.4) & $\begin{array}{c}3.03 \\
(1.32-6.92)\end{array}$ & 0.0111 \\
\hline
\end{tabular}

$\mathrm{OR}=$ odds ratio, $\mathrm{CI}=$ confidence interval and $\mathrm{p}=$ probability. The variables followed by letters in the columns differ significantly $(\mathrm{p}<0.05)$.

Source: Elaboration of the authors.

No significant differences were noted among the following variables: accumulation of rain water near the house $(p=0.081)$; accumulation of rain water inside the house $(\mathrm{p}=0.307)$; flooded areas near the house $(p=0.770)$; rivers or lakes near the house $(p=0.800)$; forest regions near the house $(p=0.470)$; vacant land near the house $(p=0.773)$; sewage disposal $(p=0.071)$; garbage disposal $(p=0.477)$; presence of debris inside the house $(p=0.621)$; presence of a toilet outside the house $(p=0.053)$; gender $(p=0.056)$; breed $(p=0.197)$; contact with dogs inside the house $(p=0.463)$; contact with rodents $(p=0.083)$; contact with cattle $(p=0.503)$; contact with possums ( $\mathrm{p}=0.251)$; access to the street $(p=0.102)$; or hunting habits $(p=0.233)$.

\section{Discussion}

The majority of studies on the seroprevalence of canine leptospirosis in dogs considered to be domiciled indicate rates of infection below $18.0 \%$ in different states of Brazil (FÁVERO et al., 2002; MASCOLLI et al., 2002; LOPES et al.,
2005; MODOLO et al., 2006; MAGALHÃES et al., 2007; SILVA et al., 2009; SPOHR, 2009; MORIKAWA, 2010; GONÇALVES et al., 2010), whereas in stray dogs, a seroprevalence of $21.6 \%$ has been described in São Paulo, São Paulo state (SP) (YASUDA; SANTA ROSA; YANAGUITA, 1980), a seroprevalence of $21.2 \%$ in Londrina, PR (BENITEZ et al., 2010) and a seroprevalence of $20.0 \%$ in Patos, Paraíba (PB) (BATISTA et al., 2004). In the present study, the prevalence of antileptospiral antibodies in pet dogs $(20.2 \%)$ was similar to that described in stray dogs and can be related to the free access of the studied dogs to the street and the frequency of contact with stray dogs or places that could be contaminated with leptospires.

The detection of the serovar Canicola as the most likely in $89(76.07 \%)$ of the seroreactive dogs in the urban area of the municipality of Jataizinho, PR, is consistent with the results described by Rubel et al. (1997), who indicated the free access of dogs to the street as the most important risk factor for canine leptospirosis, particularly for the serovar Canicola. 
Dogs are considered to be the main reservoirs of the serovar Canicola, and as asymptomatic carriers, they can eliminate bacteria in the urine over long periods without showing signs of infection (FAINE et al., 1999). Direct contact between healthy dogs and dogs that are asymptomatic carriers of leptospires can favor the transmission of Leptospira spp., given the species' behavior of smelling the urine of other animals and licking the genitals of females in heat. These behaviors may have been responsible for the high prevalence of dogs with antibodies against the serovar Canicola found in this study.

Of the 89 pet dogs that were found to be reactive to the serovar Canicola, $61(68.54 \%)$ had direct contact with stray dogs. Access to the street without supervision was reported by the owners of 53 dogs, whereas eight other dogs, though kept under restraint in the backyards of their homes, had direct contact with stray dogs inside the household due to the lack of protective walls or fences around the houses.

In Brazil, several authors who have studied pet dogs in urban areas have detected a higher prevalence of seroreactive animals among adult and elderly dogs and associated this finding with the greater period of exposure and frequency of contact with different routes of transmission, represented by places contaminated by Leptospira spp. and stray dogs with leptospiruria (MASCOLLI et al., 2002; MAGALHÃES et al., 2007; FRAGA, 2008). In the present study, the variable of adult or elderly dogs was associated with dogs that were seroreactive in the MAT, which emphasizes the need to prevent the contact of pet dogs with stray dogs by controlling their access to the street.

Antibodies against the serovar Canicola can be detected after vaccination; however, a lack of vaccination against leptospirosis was reported in $100 \%$ of the dogs, which excluded the presence of vaccine antibodies. The high prevalence observed for this serovar was likely caused by exposure of these animals to leptospires in the environment and urine of infected dogs, which suggests a high circulation of this serovar and serves as an alert for the utilization of antileptospiral vaccines in the canine population of the studied area.

The presence of rodents was reported in $73.9 \%$ of households and was considered to be a risk factor associated with the seroprevalence of dogs with anti-leptospiral antibodies. The presence of these rodents, described by the residents as mice, which could be both Mus musculus and/or Rattus rattus, could influence the prevalence of dogs' reactivity to the serovar Ballum; however, the habit of hunting rodents was not described for the dogs included in the study, limiting their direct contact with these animals. It is possible that the lack of dog owner observation could influence this variable. The dogs' indirect contact with the urine of rats was likely small, which may explain the low prevalence (3.4\%) observed for this serovar.

In contrast to the majority of studies conducted on dogs in urban areas (VIEGAS et al., 2001; QUERINO et al., 2003; SILVA et al., 2009; MORIKAWA, 2010), the serovar Icterohaemorrhagiae was not detected in the dogs included in the present study. Given the residents' reports on the rodents observed in the household, this result would be expected, as according to Faine et al. (1999), the main reservoir of this serovar in urban areas is the sewer rat (Rattus norvegicus). Spohr (2009) detected no antibodies against the serovar Icterohaemorrhagiae in 172 rodents captured in 25 locations used for recycling collected solid residues and old iron in Londrina, PR. All of the captured rodents were identified as Rattus rattus, which is not considered to be a reservoir of the serovar Icterohaemorrhagiae.

The lower frequency of seroreactive dogs for the serovars Butembo (5.9\%), Pyrogenes (4.2\%), Grippotyphosa (4.2\%) and Bratislava (2.5\%) suggest the minimal contact of these dogs with reservoirs for these serovars. Similar results were detected by Lilenbaum, Rodrigues and Barboza (2000) when evaluating the relationship between different serovars of leptospires in the urban canine population of Oriximiná, Pará (PA), and the local 
wildlife. These authors concluded that the possibility of contact with these animals was not decisive in the epidemiology of canine leptospirosis.

According to Mascolli et al. (2002), the variants that circulate in the human and dog populations are the same, given that the proximity of these populations leads to their exposure to the same risk factors. During the period of study on dogs in the municipality of Jataizinho, PR, the serovar Canicola was detected by MAT in one human patient who had symptoms of chronic renal failure (*verbal communication). This result, associated with the high frequency of antibodies detected for serovar Canicola in the dogs included in the study, suggests the participation of pet dogs in the transmission of leptospirosis to humans in this municipality.

\section{Conclusion}

The high prevalence of pet dogs in the urban area of Jataizinho, PR, with anti-leptospiral antibodies, especially against serovar Canicola, indicates the need to adopt measures that will prevent the contact between pet and stray dogs, with the aim of interrupting the transmission cycle of these bacteria. The vaccination of dogs as wellas owners knowledge of the epidemiological role of these animals in this important zoonosis is also essential.

\section{Ethics committee}

Approved by the Animal Experimentation Ethics Committee of the State University of Londrina, PR (CEEA/UEL), under protocol number 32/10.

*Vanat, N. Dissertation (Master's Degree in Animal Science) State University of Londrina, PR. Partial results.

\section{References}

ALMEIDA, L. P.; MARTINS, L. F. da S.; BROD, C. S.; GERMANO, P. M. L. Levantamento soroepidemiológico de Leptospirose em trabalhadores do serviço de saneamento ambiental em localidade urbana da região sul do Brasil. Revista de Saúde Pública, v. 28, n. 1, p. 76-81, 1994.

ALVES, M. C. G. P.; MATOS, M. R.; REICHMANN, M. L.; DOMINGUEZ, M. H. Dimensionamento da população de cães e gatos do interior do Estado de São Paulo. Revista de Saúde Pública, v. 39, n. 6, p. 891-897, 2005.

BATISTA, C. S. A.; AZEVEDO, S. S.; ALVES, C. J.; VASCONCELLOS, S. A.; MORAIS, Z. M.; CLEMENTINO, I. J. LIMA, F. S.; ARAÚJO NETO, J. O. Soroprevalência para leptospirose em cães errantes da cidade de Patos, Estado da Paraíba, Brasil. Brazilian Journal of Veterinary Research and Animal Science, v. 41, n. 2, p. 131-136, 2004.

BENITEZ, A.; RODRIGUES, G. G.; GONÇALVES, D. D.; BURKE, J. C.; ALVES, L. A.; MÜLLER, E. E.; FREITAS, J. C. Leptospirose em cães errantes encontrados em campus universitário: avaliação sorológica e exame direto da urina. Semina: Ciências Agrárias, Londrina, v. 31, n. 1, p. 191-196, 2010.

BROD, C. S.; ALEIXO, J.A.G.; JOUGLARD, S. D. D.; FERNANDES, C. P. H.; TEIXEIRA, J. L. R.; DELLAGOSTIN, O. A. Evidence of dog as a reservoir for human leptospirosis: a serovar isolation, molecular characterization and its use in a serological survey. Revista da Sociedade Brasileira de Medicina Tropical, Uberaba, v. 38, n. 4, p. 294-300, jul./ago. 2005.

DEAN, A. G.; DEAN, J. A.; COULOMBIER, D.; BRENDEL, K. A.; SMITH, D. C.; BURTON, A. H.; DICKER, R. C.; SULLIVAN, K.; FAGAN, R. F.; ARNER, T. G. Epi Info, Version 6: a word processing, data bases, and statistic program for epidemiology on microcomputers. Atlanta, Georgia: Center for Diseases Control and Prevention, 1994.

FAINE, S. Guidelines for the control of leptospires. 2. ed Geneva: World Health Organization. 1982. (WHO offset publication, 67).

FAINE, S.; ADLER, B.; BOLIN, C.; PEROLAT, P. Leptospira and leptospirosis. 2. ed. Melbourne: Medisci, 1999. $272 \mathrm{p}$. 
FÁVERO, A. C. M.; PINHEIRO, S. R.; VASCONCELLOS, S. A.; MORAIS, Z. M.; FERREIRA, F.; FERREIRA NETO, J. S. Most frequent serovars of leptospires in serological tests of buffaloes, sheeps, goats, horses, swines and dogs from several brazilian states. Ciência Rural, Santa Maria, v. 32, n. 4, p. 613-619, 2002.

FRAGA, D. B. M. Avaliação do apel do cão como reservatório na transmissão da leptospirose humana. Bahia. 2008. Tese (Doutorado em Biotecnologia em Saúde e Medicina Investigativa) - Fundação Oswaldo Cruz. Centro de Pesquisa Gonçalo Moniz, Salvador.

GONÇALVES, C. C.; PAES, A. C.; LANGONI, H.; SILVA, R. C. da; GRECA, H.; CAMOSSI, L. G.; GUIMARÃES, F. F.; ULLMANN, L. S. Anticorpos para Leptospira spp., Toxoplasma gondii e Neospora caninum em cães errantes albergados em canil privado. Arquivo Brasileiro de Medicina Veterinária e Zootecnia, Belo Horizonte, v. 62, n. 4, p. 1011-1014, 2010.

HARKIN, K. R.; ROSHTO, Y. M.; SULLIVAN,J.T.; PURVIS, T. J.; CHENGAPPA, M. M. Comparison of polymerase chain reaction assay, bacteriologic culture, and serologic testing in assessment of revalence of urinary shedding of leptospires in dogs. Journal of the American Veterinary Medical Association, New York, v. 222, n. 9, p. 1230-1233, 2003.

INSTITUTO BRASILEIRO DE GEOGRAFIA E ESTATÍSTICA - IBGE. Censo demográfico. 2010. Disponível em: <www.ibge.gov.br/cidadesat/topwindow. htm?1>. Acesso em: 27 dez. 2011.

JANSEN, A.; SCHÖNEBERG, I.; FRANK, C.; ALPERS, K.; SCHNEIDER, T.; KLAUS, S. Leptospirosis in Germany, 1962-2003. Emerging Infectious Disease, Atlanta, Giorgia, v. 11, n. 7, p. 1048-54, 2005.

LILENBAUM, W.; RODRIGUES, F.; BARBOZA, F. Aglutininas antileptospiras em caninos do município amazônico de Oriximiná-Pará, Brasil. Revista Brasileira de Ciência Veterinária, Niterói, v. 7, n. 3, p. 133-135, set./dez. 2000.

LOPES, A. L. S.; SILVA, W. B.; PADOVANI, C. R.; LANGONI, H.; MODOLO, J. R. Freqüência sorológica antileptospírica em cães: sua correlação com roedores e fatores ambientais, em área territorial urbana. Arquivos do Instituto Biológico, São Paulo, v. 72, n. 3, p. 289-296, jul./set. 2005 .

MAGALHÃES, D. F.; SILVA, J. A.; MOREIRA, E. C.; WILKE, V. M. L.; NUNES, A. B. V.; HADDAD, J. P. A.; MENESES, J. N. C. Perfil dos cães sororreagentes para aglutininas anti-Leptospira interrogans em Belo Horizonte, Minas Gerais, 2001/2002. Arquivo Brasileiro de Medicina Veterinária e Zootecnia, Belo Horizonte, v. 59, n. 5, p. 1326-1329, 2007.
MASCOLLI, R.; PINHEIRO, S. R.; VASCONCELLOS, S. A.; FERREIRA, F.; MORAIS, Z. M.; PINTO, C. O.; SUCUPIRA, M. C. A.; DIAS, R. A.; MIRAGLIA, F.; CORTEZ, A.; COSTA, S. S. da; TABATA, R.; MARCONDES, A. G. Inquérito sorológico para leptospirose em cães do município de Santana de Parnaíba, São Paulo, utilizando a campanha de vacinação anti-rábica do ano de 1999. Arquivos do Instituto Biológico, São Paulo, v. 69, n. 2, p. 25-32, abr./jun. 2002.

MILLER, M. D.; ANNIS, K. M.; LAPPIN, M. R.; LUNN, K. F. Variability in results of the microscopic agglutination test in dogs with clinical leptospirosis and $\operatorname{dog}$ s vaccinated against leptospirosis. Journal of Veterinary Internal Medicine, v. 25, n. 3, p. 426-432, 2011.

MINKE, J. M.; BEY, R.; TRONEL, J. P.; LATOUR, S.; COLOMBET, G.; YVOREL, J.; CARIOU, C.; GUIOT, A. L.; COZETTE, V.; GUIGAL, P. M. Onset and duration of protective immunity against clinical disease and renal carriage in dogs provided by a bi-valent inactivated leptospirosis vaccine. Veterinary Microbiology, v. 137, p. 137-145, 2009.

MODOLO, J. R.; LANGONI, H.; PADOVANI, C. R.; SHIMABUKURO, F. H.; MENDONÇA, A. O.; VICTORIA, C.; SILVA, W. B. Investigação soroepidemiológica de leptospirose canina na área territorial urbana de Botucatu, São Paulo, Brasil. Brazilian Journal of Veterinary Research and Animal Science, São Paulo, v. 43, n. 5, p. 598-604, 2006.

MORIKAWA, V. M. Estudo sorológico da infecção por Leptospira spp. em uma área de ocupação irregular e de alto risco para a doença em cães em Curitiba, PR. 2010. Dissertação (Mestrado em Sanidade Animal e Medicina Veterinária Preventiva) - Universidade Federal do Paraná, Curitiba.

PRESCOTT, J. F. Canine leptospirosis in Canada: a veterinarian's perspective. Canadian Medial Association, Canadá, v. 178, n. 4, p. 397-398, 2008.

QUERINO, A. M. V.; DELBEM, A. C. B.; OLIVEIRA, R. C.; SILVA, F. G.; MÜLLER, E. E.; FREIRE, R. L.; FREITAS, J. C. Fatores de risco associados à leptospirose em cães do munic'pio de Londrina - PR. Semina: Ciências Agrárias, Londrina, v. 24, n. 1, p. 27-34, jan./ jun. 2003.

RUBEL, D.; SEIJO, A.; CERNIGOI, B.; VIALE, A.; WISNIVESKY-COLLI, C. Leptospira interrogans en una población canina del Gran Buenos Aires: variables asociadas con la seropositividad. Revista Panamericana Salud Publica, v. 2, n. 2, p. 102-106, 1997. 
SILVA, W. B.; SIMÕES, L. B.; PADOVANI, C. R.; LANGONI, H.; LOPES, A. L. S.; MODOLO, J. R. Inquérito sorológico e distribuição espacial da leptospirose canina em área territorial urbana da cidade de Botucatu, São Paulo. Veterinária e Zootecnia, Botucatu, v. 16, n. 4, p. 656-668, 2009.

SPOHR, K. A. H. Leptospirose em ratos urbanos em Londrina, Paraná. 2009. Dissertação (Mestrado em Ciência Animal) - Universidade Estadual de Londrina, Londrina.

TRUEBA, G.; ZAPATA, S.; MADRID, K.; CULLEN, P.; HAAKE, D. Cell aggregation: a mechanism of pathogenic Leptospira to survive in fresh water. Research article. International Microbiology, Madrid, v. 7, p. 3540, 2004.

VASCONCELLOS, S. A.; BARABRINI JUNIOR, O.; UMEHARA, O.; MORAIS, Z. M.; CORTEZ, A.; PINHEIRO, S. R.; FERREIRA, F.; FAVERO, A. C. M.; FERREIRA NETO, J. S. Leptospirose bovina. Níveis de ocorrência e sorotipos predominantes em rebanhos dos
Estados de Minas Gerais, São Paulo, Rio de Janeiro, Paraná, Rio Grande do Sul e Mato Grosso do Sul no período de janeiro a abril de 1996. Arquivos do Instituto Biológico, São Paulo, v. 64, n. 2, p. 7-15, 1997.

VIEGAS, S. A. R. A.; TAVARES, C. H. T.; OLIVEIRA, E. M.; DIAS, A. R.; SANTOS, M. de F. P. Investigação sorológica para leptospirose em cães errantes na cidade de Salvador - Bahia. Revista Brasileira de Saúde e Produção Animal, Bahia, v. 2, n. 1, p. 21-30, 2001.

WARD, M. P. Seasonality of canine leptospirosis in the United States and Canada and its association with rainfall. Preventive Veterinary Medicine, v. 56, p. 203213, 2002.

YASUDA, P. H.; SANTA ROSA, C. A.; YANAGUITA, R. M. Variação sazonal na prevalência de leptospirose em cães de rua da cidade de São Paulo. Revista de Saúde Pública, São Paulo, v. 14, p. 589-596, 1980. 
